\title{
ISLAMIC FINANCE: AN \\ ATTRACTIVE NEW WAY OF FINANCIAL INTERMEDIATION
}

\author{
Munawar Iqbal \\ King Abdul Aziz University, Saudi Arabia
}

\begin{abstract}
Financial intermediation is a value-enhancing service. Banks are among the most important financial institutions in a modern economy for that service. Conventional banks use rates of interest (charged to clients and paid to depositors) on both the assets and the liabilities sides. Since interest is prohibited in Islam, Islamic financial experts have developed a number of financial instruments that avoid any involvement in interest. They take the form of either risk-and-reward sharing or trading in commodities/assets to price assets. In this paper we describe the basic features of the most important among these financial instruments. Even though Islamic banks emerged in response to market needs of Muslim clients, they are not religious institutions. Like other banks, these are profit seeking institutions, simply following a different model of financial intermediation. While it is the preferred way of banking for one fifth of humanity, it offers a wider choice of financial products to all by generating a number of benefits for the society. The successful operation of Islamic financial institutions has proven that this new model of financial intermediation is not only viable, but in many aspects, it is rather superior to the conventional model. The appealing features of the Islamic model have attracted world-wide attention. Islamic financial industry which started as a niche market in early 1970s in the Middle East has made a place for it in more than fifty countries around the globe and has grown into a multi-trillion dollars industry. This paper attempts to explain the basic features of this fascinating model.
\end{abstract}

Key Words: Financial intermediation, Islamic finance, Islamic financial products

JEL Classification Number: G2

\section{Introduction}

In any economy, there is a need to transfer funds from savers to investors because people who save are frequently not the same people, who have the ability to 
exploit the profitable investment opportunities, i.e., they are not entrepreneurs. This function is performed either directly through stock and bond markets or through the process of financial intermediation in the financial markets. Since interest is prohibited in Islam, a different model of financial intermediation was proposed in 1950s which envisaged providing modern financial services without dealing in interest. At that time, it was considered wishful thinking since interest was deeply entrenched in almost all financial dealings. However, serious research work over the next two decades proved that Islamic banking is not only feasible and viable; it is an efficient and productive way of financial intermediation. In response, several Islamic Financial Institutions (IFIs) emerged under heterogeneous social and economic milieu. What started as a small rural banking experiment in the remote villages of Egypt in early 1960s has now reached a level where many mega international banks are offering Islamic banking products. And several Western countries, following a lead from the UK, have made room for Islamic financial products/institutions in their legal structures.

The most important operators in the financial markets are commercial banks. Since the passage of the so-called Glass-Steagall Act in 1933, commercial banks' securities activities and affiliations between commercial banks and securities firms were prohibited. However, the market largely ignored the provisions of Glass-Steagall Act and they gradually faded away. They were formally repealed in 1999 through the Gramm-Leach-Bliley Act. With the passage of the Gramm-Leach-Bliley Act, commercial banks, investment banks, securities firms, and insurance companies were allowed to consolidate. Since then commercial banks are also one of the biggest players in stock and bond markets.

Financial intermediation enhances the efficiency of the saving/ investment process by eliminating many mismatches inherent in the needs of surplus and deficit units of an economy (Iqbal \& Llewellyn, 2002). The surplus units are often small households who save relatively small amounts and the deficit units are the firms who often need relatively large amounts of cash. Financial intermediaries remove this size mismatch by collecting the small savings and packaging these to make them suitable to the needs of the users. In addition, users of funds in general need funds for relatively long-term deployment, which cannot be met by individual suppliers of funds.

This creates the mismatch in the maturity and liquidity preferences of individual savers and users of funds. The intermediaries resolve the conflict again by pooling the small funds. Moreover, the risk preferences of small suppliers and large users of funds are also different. It is often considered that small savers are risk averse and prefer safer placements whereas the fund users may deploy funds in risky projects. Therefore, the funds cannot be directly supplied. The role of the intermediaries again becomes crucial. They can substantially reduce this risk through portfolio diversification. Furthermore, small savers cannot efficiently gather information about investment opportunities. Financial intermediaries are 
in a much better position to collect such information, which is crucial for making the investment successful.

The role and functions of banks outlined above are indeed highly useful and socially desirable, but interest plays a central role in each of these functions. Islamic financial intermediation endeavors to replace interest by partnership between owners of capital and human resources (entrepreneurs) on the basis of risk/profit sharing as a basic form of co-operation between capital and entrepreneur. Trading activities are also an integral component of Islamic banking.

\section{Basic Principles of Islamic Finance}

In Islamic jurisprudence there are two kinds of Rulings (arkām). The first ruling is called $i b \bar{a} d \bar{a} t$ (worshipping) which governs the relationship between a man and his God. The general principal in case of $i b \bar{a} d \bar{a} t$ is that nothing is permitted unless endorsed by authentic and explicit analogical permission by the Law Giver. In other words, an act is considered worship only if so ordained. The second ruling is of arkām, called mu āmalāt (mutual dealings) which governs the relationship among mankind. In this case, the general principal is that of permissibility $(i b \bar{a} d a h)$ i.e., everything is permitted unless clearly prohibited by the Law Giver. The collection of Rulings comprises of what is called as Sharī'ah (Islamic law).

Since we are discussing the second set of Rulings, the general rule is that of permissibility. We call this the "Doctrine of Universal Permissibility". The Doctrine permits the contracting parties to agree on any conditions as long as they do not violate any Sharī' ah ruling. This is supported by a well-known authentic hadith which states:

"All conditions mutually agreed upon by the Muslims are upheld, except any condition that would allow what is prohibited or prohibit what is lawful." [Sunan Tirmidhi:1352]

This principle gives a very wide scope in designing contracts. However, the qualification, "unless clearly prohibited by Sharı̄'ah" must never be ignored. When one looks at the permissible acts and contracts and the non-permissible ones, one is struck with the very wide scope of running human relations within the boundaries of Sharī'ah in all fields of life including financial transactions. There are very few kinds of activities that are prohibited. Furthermore, when we reflect even on these prohibitions, one can easily ascertain that the purpose of such prohibitions is to provide a level playing field to protect the interests of weaker parties; to ensure justice and fairness; to ensure mutual benefit for the parties as well as the society at large; minimize chances of conflicts and promote social harmony. Islamic law is so beneficent that it not only ensures protection 
of interests of the two parties to the contract, it also protects the interests of third parties, future generation and even the en

The prohibitions are very few. In the following paragraphs we discuss those prohibitions that are most relevant for constructing financial contracts.

\subsection{Prohibition of Ribā}

Islam prohibits all forms of ribā. But what does this term encompass? The word riba as a noun literally means in Arabic, an increase, and as a root, it means the process of increasing. Riba has been understood throughout Muslim history as being equivalent to interest paid on a loan. The prohibition of riba essentially implies that the fixing in advance of a positive return on a loan as a reward for waiting is not permitted by the Sharī'ah. It makes no difference whether the return is big or small, fixed or variable or an absolute amount to be paid in advance or on maturity, or a gift or service to be received as a condition for the loan. It also makes no difference whether the loan was taken for consumption or business purposes. In its basic meaning ribā can be defined as "anything (big or small), pecuniary or non-pecuniary, in excess of the principal in a loan that must be paid by the borrower to the lender along with the principal as a condition, ${ }^{1}$ (stipulated or by custom), of the loan or for an extension in its maturity."

As mentioned in the definition of riba given above, anything, big or small, stipulated in the contract of loan to be paid in addition to the principal is riba $\bar{a}$. Such additional payment in modern terminology is known as interest. Thus rib $\bar{a}$ and interest are the same. The equivalence of rib $\bar{a}$ and interest has always been unanimously recognized in Muslim history by all schools of thought. While the basic rationale for the prohibition/condemnation of riba is moral, it creates many economic problems too. The ease of availability of credit on interest also creates inherent instability in the financial system. As Nobel laureate Maurice Allais (1993) rightly points out:

"The world economy as a whole rests today on gigantic
pyramids of debts, buttressed one against another in a fragile
equilibrium. Neverin the pasthad such acolossal accumulation
of promises to pay been witnessed. Undoubtedly, never will it
be so difficult to master. Be it speculation on currencies or
speculation on stocks and shares, the world has become one
big casino with gaming tables distributed along every latitude
and longitude. The game and the bids, in which millions of
players take part, never cease."

Iqbal (2013) dwells on the dangers and consequences of unreasonable ease of access to credit and the resulting debt overhang which has caused havoc with global economy several times, the most recent example being the still raging

\footnotetext{
${ }^{1}$ Thus any excess given by the debtor out of his own accord, and without the existence of a custom or habit that obliges him to give such excess is not considered as ribā.
} 
European debt crisis. Several other recent publications show that the root cause of these crises is excessive debt facilitated by interest-based contracts (Reinhart, Carmen \& Rogoff, 2009). It is pertinent to note here that the practice of interest has been condemned by many most prominent thinkers in human history and by all Devine religions. Mills and Presley (1999) have traced the history of prohibition of interest in Biblical texts.

The basic rationale for the prohibition of interest is based on ethics, most importantly to ensure justice to all parties. In many cases, charging of interest is also demeaning. For example, if the loan is for procuring things necessary for survival, charging interest delivers a severe blow to the very basic fabrics of social life which requires cooperation, care and help of the needy, and protecting the weaker members of the society.

\subsection{Prohibition of Gharar}

Prophet (pbuh) ${ }^{2}$ prohibited any trading activity involving 'gharar'. In jurisprudential literature, gharar has been variously defined. Mainly there are three views which are summarized by al-Darir (1997). First, gharar applies to cases of uncertainty, as in the case of not knowing whether something will take place or not. A second view holds that gharar applies trading of unknown. Thus, according to Ibn Hazm gharar in sales occurs when the purchaser does not know what he has bought and the seller does not know what he has sold. Third is a combination of the two opinions; gharar covers both the unknown and the doubtful, as exemplified by the definition proposed by Al-Sarakhsi which states that gharar obtains where consequences of a contract are not known. This is the view favoured by most jurists.

Gharar has been one of the most difficult Islamic juristic terms to explain to non-specialist. Some authors have dealt with it very comprehensively in long treaties. $^{3} \quad$ Perhaps the best way to envision its true scope and import is to list some examples.

In modern contracts, gharar appear in many ways. The most important categories are the following:

i) Ignorance of the genus. For example, saying "I sell you 1 kilogram of apples for five dollars." It involves gharar because it is not clear what type of apples are the subject of sale.

ii) Ignorance of the species. For example, saying "I sell you my pet for 100 dollars." It is not known what the pet is.

iii) Ignorance of the attributes. For example, saying "I sell you my car for 5000 dollars." It is not known which car. (However, if the object is available and offered for inspection with known defects declared then there is no gharar.)

iv) Ignorance of the quantity of the object. For example, saying "I sell you a box of oranges for 20 dollars" without mentioning the type of oranges

2 Short form for "May peace of Allah be upon the soul of Prophet Muhammad"

The best reference, in view of this author is Darir al-Siddiq (2012) 
and the weight. Branding and standardization can remove this type of gharar.

v) Ignorance about price. For example, saying "I sell you this dress for a week's salary."

vi) Ignorance of the specific identity of the object. For example, saying "I sell you one flat in this building for fifty thousand dollars." Mentioning of flat number and allowing physical inspection is necessary.

vii) Ignorance of the time of payment in deferred sales. For example, saying "I buy this house from you for 100,000 dollars which I will pay when my farm is sold."

viii) Inability/uncertainty to deliver the object. For example, saying "I sell you the bird sitting on that tree," or "I sell you my BMW which has been stolen if it is recovered for only \$1000."

ix) Contracting on a non-existent object. For example, saying "I sell you the harvest of my farm from the next crop."

$x$ Not being able to inspect the object. For example, saying "I sell you the contents of this carton for fifty dollars on as is basis."

xi) More than one option in a contract unless one is specifically chosen. For example saying "You can either take my car for ten thousand dollars," or "My boat for fifteen thousand dollars." The sale would become valid only after you exercise your option and specifically choose what you are buying.

xii) Contingent Sale. "I sell you my house for $\$ 25000$, if Peter rented his house to me."

These examples are not exhaustive but they should be sufficient in giving a fairly good idea of what the prohibition of gharar implies. In essence, gharar refers to acts and conditions in exchange contracts, the full implications of which are not clearly known to the parties. This is something very similar to 'asymmetric information'. Lack of knowledge with respect to all implications of a contract vitiates against the principle of voluntary consent of all parties which is a necessary condition in all contracts of exchange according to Islamic law. In other words, had the parties known the full implications of the contract, one (or both) of them may have preferred not to enter into that contract. In the presence of asymmetric information, the agreement of the parties cannot be considered as voluntary consent. The objective of prohibition of gharar is to minimize possibilities of post-facto misunderstandings and conflicts between the contracting parties. As such, any conditions in contracts that may give rise to ambiguities and/or misinterpretations and are preventable must be avoided.

Jurists make a distinction between two types of gharar: gharar fāhish (substantial) and gharar yaseer (trivial). The first type is prohibited while the second is 'tolerated' since this may be unavoidable without causing considerable damage to one of the parties with the possibility of post-facto conflict. In many cases, it is simply not possible to reveal all information; not because the seller wants to hide anything, but because it is in the nature of the subject matter. The 
buyer has to trust the seller. For example, the buyer of a built house has to take the word of the seller as to what kind of material is used in the foundations of the house. The seller obviously cannot dismantle the house to reveal the foundations to the buyer. His intention is not to hide essential information, but the nature of the subject matter of the contract is such that he cannot show it to the buyer. Therefore, such lack of knowledge does not violate contracts. The principle in such cases is that the seller must act as a trustworthy person. Penalties may be imposed ex-post if it is proved otherwise.

In the literature, some other prohibited types of trade or conditions therein are also mentioned. For example, the following cases are mentioned: prohibition of selling something not owned; ghish (cheating, for example adulteration); two mutually inconsistent contracts with (conditions) bunched into one contract; $i k r a \bar{h}$ (coercion); ghaban (fraud); But on closer examination one finds that these are covered by the prohibition of gharar.

In economic parlance the term is very close to "Asymmetric Information." Its prohibition necessitates 'full disclosure' by all parties of a contract. Any intentional concealment renders the contract void. Small, unintentional or unavoidable lack of disclosure (gharar yaseer) is tolerated (not to be considered allowed). Post contract exposure is still subject to legal recourse for compensation.

\subsection{Prohibition of Gambling}

Gambling involves transfer of wealth without any value added. It is zero-sum game and does not make any addition to the national wealth. Prohibition of gambling implies prohibition of all zero-sum games and taking risks that are self-created. As compared to this, taking risk which are normally involved in almost all business activities do not come under the purview of gambling. Islamic financial contracts encourage sharing of these risks among the parties.

\subsection{Loan and trade contracts cannot be combined}

This is prohibited by an authentic hadith. The rationale for this prohibition can easily be seen. If allowed, a lender may advance the loan on an interest-free basis in the loan part of the deal but they can buy something at a cheaper price in the sale part of the deal which amounts to ribā.

\subsection{Two deals cannot be combined into one}

The Prophet (pbuh) prohibited "two deals in one". Some scholars take this hadith as a general prohibition of combining contracts. However, actually it implies that if more than one option is offered, one must be chosen before the deal is finalised. For example, if a seller offers a product for sale such as: (i) $\$ 1000$ on cash payment basis; (ii) $\$ 1100$ on payment after six months; (iii) $\$ 1500$ on payment after one year etc., the buyer must choose one of the options and close the deal. The rationale of such prohibition is that it amounts to gharar which, as 
stated above, is prohibited in business contracts. The seller will not know when (and hence how much money) he will receive.

\subsection{Right to profit is contingent upon taking responsibility (for loss)}

This is in line with the principle of justice to all parties. In the field of financial contracts, any condition which gives a party assured benefit without him taking any risk is not allowed. For example, in an interest-based loan contract the lender's capital is guaranteed, yet he gets a positive return. All risk of loss is borne by the borrower. That is not allowed. As compared to this, in a mudārabah contract, if a loss occurs the financier bears the monetary loss and the entrepreneurs loses any return for his efforts. In other words, the capitalist loses part of the money capital and the entrepreneur loses 'sweat capital'. Thus both parties share profit in case of profit and loss in case of loss.

\section{Islamic Banking and Finance: A Different Way of Financial Intermediation}

Islam fully recognizes the useful role that financial intermediation can play value. Historically, the role of a financial intermediary in the Islamic economy is found in the principle of al-mudāarib udārib; a practice which has existed in Islamic history since early centuries. It can be expressed as, "the one who mobilizes funds, on profit-sharing basis, can extend these funds to the users on the same basis". Similarly, in leasing, the lessee who possesses the usufruct, may sell these against a higher price (rent), and create additional value. In the early Islamic period, most caravan trades were financed by mudārabah (trust financing) and money transfer was quite common among businessmen. Islamic scholars consider the earning of profits from an intermediary role as a genuine occupation. It is however, noticeable that such financial intermediation is interwoven with the production and exchange of real goods and services.

The functions of Islamic banks and other financial intermediaries are similar to their conventional counter-parts. Islamic finance experts have shown that there are alternative Islamic modes and models through which these functions can be performed. In fact, they have shown that Islamic models can perform these functions in a better way. An Islamic bank, like other banks, is a company whose main business is to mobilize funds from savers and supply these funds to businessmen/entrepreneurs. It is organized as a joint stock company with the shareholders supplying the initial capital. While a conventional bank uses the rate of interest for both obtaining funds from savers and supplying these funds to businessmen, an Islamic bank performs these functions using various financial modes compatible with the Sharı̄'ah. These will be described later in the paper. First we would like to present the most basic features of Islamic finance.

While Islamic banks perform mostly the same functions as conventional banks, they do this in distinctly different manners. Some of the distinguishing features of Islamic banking are given below: 


\subsection{Risk Sharing}

The most important feature of Islamic banking is that it promotes risk-sharing between the provider of funds (investor) and the user of funds (entrepreneur). By contrast, under conventional banking, the investor is assured a predetermined rate of interest. Since the nature of this world is uncertain, the results of any project are not known with certainty ex-ante. Therefore, there is always some risk involved. In conventional banking, all this risk is borne by the entrepreneur. Whether the project succeeds and produces a profit or fails and produces a loss, the owner of capital gets away with a predetermined return. ${ }^{4}$ In Islam, this kind of unjust distribution is not allowed. In Islamic banking both the investor and the entrepreneur share the results of the project in an equitable way. In the case of profit, both share this in pre-agreed proportions. In the case of loss, all financial loss is borne by the capitalist and the entrepreneur loses his labour. Askari, Iqbal, Krichene and Mirakhor (2012) discuss in detail on what benefits risk/profit sharing model of financial intermediation brings to an economy.

\subsection{Emphasis on Productivity Relative to Credit Worthiness}

Under conventional banking, almost all that matters to a bank is that its loan and the interest thereupon are paid on time. Therefore, in granting loans, the dominant consideration is the credit-worthiness of the borrower and/or his providing sufficient collateral as a cover. Under Profit and Loss Sharing (PLS) banking, the bank will receive a return only if the project succeeds and produces a profit. Therefore, an Islamic bank will be more concerned with the soundness of the project and the business acumen and managerial competence of the entrepreneur. This feature has important implications for the distribution of credit as well as the stability of the system. Chapra (2000) lists the limitations/ harms of a collateral-based banking.

\subsection{Moral Dimension}

Conventional banking is secular in its orientation. In contrast, in the Islamic system all economic agents have to work within the moral value system of Islam. Islamic banks are no exception. As such, they cannot finance any project which conflicts with the moral value system of Islam. For example, they will not finance a wine factory, a casino, a night club or any other activity which is prohibited by Islam or is known to be harmful to society. In this respect Islamic banks are somewhat similar to "Ethical Funds" which are now becoming popular in the Western world.

\footnotetext{
4 Except in the extreme case of bankruptcy.
} 


\subsection{Close linkages between monetary and real sectors}

In Islamic model of financial intermediation, there is a close link between the monetary and real sectors of the economy. The financial products are either asset-backed or trade-linked. In this way 'pure' speculation is eliminated. This feature provides a safeguard against forming of artificial economic bubbles that often lead to economic and financial instability

\subsection{Wider Set of Products}

An important point to be noted in the way Islamic banking works is that it offers a wider choice of products. In addition to some fixed-return modes that can serve necessarily the same functions that interest serves in conventional banking, Islamic banks can use a variety of innovative profit-sharing financing techniques. The addition of various profit-sharing modes, which can be designed to meet the needs of different classes of risk-takers, to the menu of available financial products, renders several advantages, which will be noted later in the paper.

\section{Islamic Financial Products}

In this section we briefly explain the most commonly used financial products being used by Islamic financial institutions and lately by corporations and governments.

\subsection{Mushārakah (Partnership)}

Mushārakah literally means sharing. In the Islamic finance literature it refers to a joint enterprise in which all the partners share the profit or loss of the joint venture. The financial term is derived from the Islamic legal term "shirkah" with the same literal meaning but having a broader application. In the Islamic fiqh literature shirkah is of two kinds: The first is shirkat-ul-milk which means joint ownership of two or more persons of a particular property/asset which may come into existence either through inheritance or joint purchase. The second kind of shrikah is shirkat-ul-'aqd, which means a partnership established through a contract. Such contractual partnerships are usually established for commercial purposes and take several forms such as partnership in the capital of the enterprise, partnership in labour and management, common goodwill or a combination of these elements.

Mushārakah as a financial contract refers to an arrangement where two or more parties establish a joint commercial enterprise and all contribute capital as well as labour and management as a general rule. The profit of the enterprise is shared among the partners in agreed proportions while the loss will have to be shared in strict proportion of capital contributions. The basic rules governing the mushārakah contract include: 
i) Profit of the enterprise can be distributed in any proportion by mutual consent. However, it is not permissible to fix a lump sum profit for anyone.

ii) In case of loss, it has to be shared strictly in proportion to the capital contributions.

iii) As a general rule all partners contribute both capital and management. However, it is possible for any partner to be exempted from contributing labour/management. In that case, the share of profit of the sleeping partner has to be in strict proportion of his capital contribution.

iv) The liability of all the partners is unlimited.

As a mode of finance, an Islamic bank can advance money to a client using the contract of mushärakah. Normally the bank will use the option of being a sleeping partner. The contract can be more widely used by Islamic funds whereby the unit holders can assume the role of sleeping partners. The contract can also be used in securitized assets.

\subsection{Mudārabah (Passive Partnership)}

Mudārabah is a special type of partnership. This is a contract between two parties: ${ }^{5}$ a capital owner (called rabb al-māl) and an investment manager (called mudārib). Profit is distributed between the two parties in accordance with the ratio that they agree upon at the time of the contract. Financial loss is borne by the capital owner; the loss to the manager being the opportunity cost of his own labour, which fails to generate any income. Except in the case of a violation of the agreement or default, the investment manager does not guarantee either the capital extended to him or any profit generation. Some other important features of the mudārabah contract include:

i) While the provider of capital can impose certain mutually agreed conditions on the manager, he has no right to interfere in the day-to-day work of the manager.

ii) Mudārabah is one of the fiduciary contracts. Mudārib is expected to act with utmost honesty, otherwise he is considered to have committed a grave sin (in addition to worldly penalties). This has important implications for the moral hazard problem.

iii) The liability of the rabb al-māl is limited to the extent of his contribution to the capital.

iv) The mudārib is not allowed to commit the mudārabah business for any sum greater than the capital contributed by the rabb al-māl.

v) All normal expenses related to mudārabah business, but not the personal expenses of the mudārib, can be charged to the mudārabah account ${ }^{6}$.

\footnotetext{
5 There could be more than two parties. The contract is explained using a two-party example only for simplicity.

${ }^{6}$ However, in case of travelling outside the place of business, the muロärib is entitled to travel and living expenses during the trip.
} 
vi) The contract of mudārabah can be terminated at any time by either of the two parties on giving a reasonable notice. (This condition may create serious problems in the context of modern commercial enterprises. However, in the light of the 'Doctrine of Universal Permissibility' mentioned above, the parties can agree on any conditions in the contract that will regulate the termination so as not to cause any damage to the enterprise).

vii) No profit distribution can take place (except as an ad hoc arrangement, and subject to final settlement), unless all liabilities have been settled and the equity of the rabb al-māl restored.

As a mode of finance applied by Islamic banks, on the liabilities side, the depositors serve as rabb al-māl and the bank as the mudarib. Mudärabah deposits can be either general, which enter into a common pool, or restricted to a certain project or line of business. On the assets side, the bank serves as the $r a b b$ $a l-m \bar{a} l$ and the businessman as the mudārib (manager). However the manager is often allowed to mix the mudārabah capital with his own funds. In this case profit may be distributed in accordance with any ratio agreed upon between the two parties, but the loss must be borne in proportion to the capital provided by each of them.

\subsection{Diminishing Partnership}

This is a contract between a financier (e.g., a bank) and a beneficiary in which the two agree to enter into a partnership to own an asset, as described above, but on the condition that the financier will gradually sell his share to the beneficiary at an agreed price and in accordance with an agreed schedule.

\subsection{Bay al- murābahah (Sales Contract at a Profit Mark-up)}

In the classical fiqh literature, there is a sales contract called bay al-mu'ajjal which refers to sale of goods or property against deferred payment (either in lump sum or instalments). Bay al-mu'ajjal need not have any reference to the profit margin that the supplier may earn. Its essential element that distinguishes it from cash sales is that the payment is deferred. Strictly speaking, the deferred payment can be higher than, equal to or lower than the cash price.

There is another sale contract known as bay al-murābahah, which refers to a sale in which the seller declares his actual cost and the parties agree on adding a specific profit margin. Basically, this is a two party buying and selling contract. No financial intermediation is involved. The Islamic banks have created a mode of finance by combining the concepts of bay al-mu'ajjal and bay al-murābahah. They use this contract as a mode of finance in the following manner.

The client orders an Islamic bank to purchase for him a certain commodity at a specific cash price, promising to purchase such commodity from the bank once it has been bought, but at a deferred price, which includes an agreed upon profit margin called mark-up in favour of the bank. Thus, the 
transaction involves an order accompanied by a promise to purchase and two sales contracts. The first contract is concluded between the Islamic bank and the supplier of the commodity. The second is concluded between the bank and the client who placed the order, after the bank has possessed the commodity, but at a deferred price, that includes a mark-up. The deferred price may be paid as a lump sum or in instalments. In the contract between the Islamic bank and the supplier, the bank often appoints the person placing the order (the ultimate purchaser) as its agent to receive the goods purchased by the bank. The basic rules governing the murābahah contract include:

i) The subject of sale must exist at the time of sale.

ii) The subject of sale must be in the ownership of the seller at the time of sale.

iii) The subject of sale must be in the physical or constructive possession of the seller.

iv) The delivery of the sold commodity to the buyer must be certain and should not depend on a contingency or chance.

v) As in any sales contract the price must be specified and once specified it cannot be increased in case of default.

vi) The time of delivery must be specified.

vii) The payments schedule must be specified.

\subsection{Ijārah (Leasing)}

In the simple lease contract the usufruct generated over time by an asset, such as machinery, airplanes, ships or trains is sold to the lessee at a predetermined price. This is called an operating lease, as opposed to a financial lease. The operating lease has a number of features that distinguish it from other forms of leasing. Firstly, the lessor is himself the real owner of the leased asset and, therefore, bears all the risks and responsibilities of ownership. All defects, which prevent the use of the equipment by the lessee, are his responsibility, even though it is possible to make the lessee responsible for the day-to-day maintenance and normal repairs of the leased asset. Secondly, the lease is not for the entire useful life of the leased asset but rather for a specified short-term period (for a month, a quarter, or a year) unless renewed by mutual consent of both the parties.

\subsection{Ijärah wa iqtina' (Lease Ending in the Purchase of the Leased Asset)}

Since the entire risk is borne by the lessor in the operating lease, there is a danger of misuse of the leased asset by the lessee. The financial lease helps taking care of this problem by making the lease period long enough (usually the entire useful life of the leased asset), to enable the lessor to amortize the cost of the asset with profit. At the end of the lease period the lessee has the option to purchase the asset from the lessor at its market value at that time. The lease is not cancellable before the expiry of the lease period without the consent of both the parties. There is, therefore, little danger of misuse of the asset. 
A financial lease has other advantages too. The leased asset serves as a security and, in case of default on the part of the lessee, the lessor can take possession of the equipment without court order. It also helps reduce the lessor's tax liability due to the high depreciation allowances generally allowed by tax laws in many countries. The lessor can also sell the equipment during the lease period such that the lease payments accrue to the new buyer ${ }^{7}$. This enables the lessor to get cash when he needs liquidity. This is not possible in the case of a debt because, while the Sharî'ah allows the sale of physical assets, it does not allow the sale of monetary debts except at their nominal value.

Some of the jurists have expressed doubts about the permissibility of financial leases. The rationale they give is that the long-term and non-cancellable nature of the lease contract shifts the entire risk to the lessee, particularly if the 'residual' value of the asset is also fixed in advance. The end result for the lessee may turn out to be worse than the outright purchase of the asset through an interest-bearing loan. A financial lease has thus the potential of becoming more exploitative than outright purchase. Suppose the lease contract is for five years. The lessee would have to continue making lease payments even if he does not need the asset, say, after two years. In the case of a purchase through an interest-bearing loan, the purchaser can sell the asset in the market and repay the loan, thus reducing his loss. This cannot be done in a financial lease. If a party is unable to make lease payments, it may lose its stake in the asset even though part payment of the asset price has been made beyond the rental charge he would normally pay in an operating lease.

However, there are jurists who consider financial leases to be permissible if certain conditions are satisfied. Firstly, the lessor must bear the risks of leasing by being the real owner of the leased asset. The lessor cannot lease what he does not own and possess, and should be responsible for all the risks and responsibilities related to ownership. Therefore, a leasing contract where the lessor acts only as an intermediary between the supplier and the lessee and plays the role of only a financier, with ownership of the asset being nothing more than a legal device to provide security for repayment of the loan and legal protection in case of default, is not allowed. In this case the lessor leases an asset before buying and taking possession and gets a reward without bearing any risk. Secondly, lease payments cannot start until the lessee has actually received possession of the leased asset and can continue only as long as it remains usable by him. Thirdly, all manufacturing defects and later damages which are beyond the control of the lessee, should be the lessor's responsibility ${ }^{8}$. The lessee can, however, be made responsible for the proper upkeep and maintenance of the leased asset.

As a form of financing used by Islamic banks in practice, the contract takes the form of an order by a client to the bank, requesting the bank to purchase a piece of equipment, promising, at the same time, to lease it from the bank after

\footnotetext{
7 The new buyer has to agree to continue the lease on the conditions previously agreed unless the lessee willingly agrees to new conditions.

8 Some of these can be insured against, but this has to be done by the lessor at his own cost.
} 
it has been purchased. Rent instalments are calculated in such a manner as to include, in reality, recovery of the cost of the asset plus the desired profit margin. Thus, this mode of financing includes a purchase order, a promise to lease, and a leasing contract with a provision to transfer ownership of the leased asset to the lessee at the end of the lease agreement. This transfer of ownership is made through a new contract, in which the leased asset is either given to the lessee as a gift or is sold to him at a nominal price at the end of the lease agreement. According to a decision of the International Islamic Fiqh Academy, this second transfer-of-ownership contract should be signed only after termination of the lease term, on the basis of an advance promise to affect such a transfer of ownership to the lessee.

\subsection{Bay al-Salam}

Bay al-Salam (usually written in short form as salam) is a sales contract in which the price is paid in advance at the time of contracting, against delivery of the purchased goods/services at a specified future date. Not every commodity is suitable for a salam contract. It is usually applied only to fungible commodities. Some basic rules governing the salam sale are given below:

i) The price should be paid in full at the time of the contract.

ii) Goods whose quality or quantity cannot be determined by specification cannot be sold through the contract of salam. An example is precious stones.

iii) Goods can be sold only by specifying the attributes. They cannot be particularized to a given farm, factory or area.

iv) The exact date and place of delivery must also be specified.

Islamic banks can provide financing by way of a salam contract by entering into two separate salam contracts, or one salam contract and an instalments sale contract. For example, the bank could buy a commodity by making an advance payment to the supplier and fixing the date of delivery as the date desired by its client. It can then sell the commodity to a third party either on a salam or instalments sale basis. If the two were salam contracts, the second contract would be for delivery of the same quantity, description, etc., as that constituting the subject-matter of the first salam contract. This second contract is often concluded after the first contract, as its price has to be paid immediately upon conclusion of the contract. To be valid from the Sharî' ah point of view, the second contract must be independent, i.e., not linked to the delivery in the first contract. Should the second contract consist of an instalments sale, its date should be subsequent to the date on which the bank would receive the commodity.

\subsection{Bay al-istisnah (Contract to Manufacture) and Bay al-istisnah al-Tamwilī (Financing by Way of istisnah )}

Bay al-istisna (usually written in short form as istisna) is a contract in which a party orders another to manufacture and provide a commodity, the description of 
which, delivery date, price and payment date are all set in the contract. Any party can cancel the contract after giving a notice to the other before the manufacturing work starts. However, after the manufacturing work has started, the contract cannot be cancelled unilaterally.

Istisna is similar to salam in the sense that both are exceptions to some general conditions of sale which prohibit selling of something which is not owned and is not in the possession of the seller at the time of sale. However, there are some differences between the two which are summarized below:

i) The subject of istisnah is always a thing which needs manufacturing, while salam can also be effected on things that do not involve manufacturing.

ii) In the case of salam full payment of price is necessary whereas in case of istisnah the payment can be delayed.

iii) The time of delivery in case of salam must be specified at the time of the contract. In the case of istisnah this is not necessary.

Al-istisnah al-tamwili , which is used by Islamic banks, consists of two separate istisnah contracts. The first is concluded between the beneficiary and the bank, in which the price is payable by the purchaser in future, in agreed instalments and the bank undertakes to deliver the requested manufactured commodity at an agreed time. The second istisnah contract is a subcontract concluded between the bank and a contractor to manufacture the product according to prescribed specifications. The bank would normally pay the price in advance or during the manufacturing process in instalments. The latter undertakes to deliver the product to the bank on the date prescribed in the contract, which is the same date as that stated in the first istisnah contract. The original purchaser (i.e., the bank's client) may be authorized to receive the manufactured commodity directly from the manufacturer.

\subsection{Wakālah (Agentship)}

Wakālah is a contract whereby someone appoints another to act in/pursue some matter on his behalf. It is permissible to charge a fee for providing such services. In Islamic finance, the contract is being used extensively in the area of Fund Management. Under this contract, an Islamic bank serves as an investment manager for some clients. Usually the bank establishes a Mutual Fund in which clients buy units. The Fund promoter (Bank) is the wakil (agent) of the unit holders and charges a fixed fee for its services. The profit or loss is passed on to the Fund providers after deducting Bank's fees. It is worth noting that mutual funds are different from mudārabah accounts in the Islamic banks. The basic difference between the two is that in the latter case the bank is mudārib and hence shares in the risk of investment. In case of investment funds, all risk (loss) is borne by the unit holders. For the same reason, the Fund promoters have no share in profits, all of which after deducting fixed management fees of the promoters, is passed on to the unit holders. 


\subsection{Tawarruq}

In many cases the clients would need liquidity which cannot be linked to purchase of commodities. Conventional financial system has the capability of providing cash for those who want it, provided they are willing to give back more than they borrow and are able to provide a collateral or guarantee. Islamic financial system does not have this facility. Recently, some banks have started using a new instrument called tawarruq.

In the classic fiqh literature there is an instrument called tawarruq for obtaining cash in case of difficulties facing an individual. It works like this. Suppose A asks B for a loan. B says that I do not have any cash but I can lend you one bushel of wheat. A takes that loan in kind, sells it in the market and gets the cash that he needed. At the time of repayment, A goes to the market buys a bushel of wheat of the same quality and returns it to A. In essence, this is an arrangement of loan in kind. Since one of the conditions of loan is that the ownership must be transferred to the borrower, he can do whatever he wants with the borrowed commodity. Thus his selling it for cash is legitimate. Since what he returns after the period of the loan is exactly the quantity borrowed, there is no question of $r i b \bar{a}$ in this kind of deal. Hence, the arrangement is permissible.

However, the way this instrument is being practiced by banks is a lot more different. It appears to be simply a 'devious artifice' (ilah) to go around prohibition of interest through an intermediate process, the end result being what was prohibited. Say, A goes to the bank for obtaining cash on loan. On the request of the client, the bank buys, at a credit price, on client's behalf some commodities on paper. In order to do that A signs a wakālah contract appointing the bank as his agent for this purchase. Bank certifies that it has done so at, say a credit price of $\$ 1.0$ million due after one year. A becomes owner of these commodities. He now signs another wakälah contract, this time appointing the bank as his agent to sell those commodities. Bank certifies that it has done so at a cash price of $\$ 900,000$ and pays this amount to A. All of these transactions are only on paper. It can easily be seen that it is money obtained now $(\$ 900,000)$ for more money to be paid later ( $\$ 1.0$ million). The real asset involved in the process is no more than a dummy. A single piece of real asset can form the basis of innumerable successive tawarruq deals.

There are a few scholars who have allowed tawwaruq argued on the basis of the example given above in the classic fiqh literature. However, one can easily see that the two are far apart. Therefore, even those scholars place some restrictions to be complied with, if this instrument is to be declared Sharī'ah-compatible. Basically, they require the banks to actually buy and take at least constructive possession of the commodities involved and then sell them. According to my information almost all of the banks using this instrument are not complying with those conditions. Hence, I believe that it is only a subterfuge for a riba $\bar{a}$ transaction. 


\subsection{Bay al-Dayn (Sale of debt)}

Many Islamic instruments, the most prominent example being bay al-murābahah, give rise to debt obligations. Can such debt be sold at a discount in order to obtain immediate cash? According to a majority of Islamic scholars, sale of debt is not permissible except at face value. The traditional Muslim jurists are unanimous on the point that sale of debt is possible only on its face value. ${ }^{9}$ Discounting debt is not allowed in Sharî'ah. The overwhelming majority of the contemporary Muslim scholars are of the same view. However, some scholars of Malaysia have allowed selling debt at a discounted price. They refer to a ruling of Shafai school wherein it is held that the sale of debt is allowed. They did not pay attention to the fact that the Shafai jurists have allowed it only in a case where the debt is sold at its par value.

In fact, the prohibition of bay al-dayn is a logical consequence of the prohibition of riba $\bar{a}$. A 'debt' receivable in monetary terms corresponds to money, and every transaction where money is exchanged for the same type of money, the exchange must be at par value. Any increase or decrease from one side is tantamount to ribā. Some scholars argue that the permissibility of bayal-dayn is restricted to a case where the debt is created through the sale of a commodity. In this case, they say, the debt represents the sold commodity and its sale may be taken as the sale of a commodity. Such an argument is not correct. For, once the commodity is sold, its ownership is passed on to the purchaser and it is no longer owned by the seller. What the seller owns is nothing other than money due. Therefore, if he sells the debt, it is no more than the sale of money and it cannot be termed as the sale of the commodity. That is why this view has not been accepted by the overwhelming majority of the contemporary scholars. The International Islamic Fiqh Academy of Jeddah, which is the largest representative body of Sharī'ah scholars and has the representation of all the Muslim countries, including Malaysia, has unanimously upheld the prohibition of bay al-dayn at a discount. ${ }^{10}$

\subsection{Ju ālah}

$J u$ älah is a contract whereby one party (offerer) undertakes to pay a prescribed fee to the second party (offeree) for performing a given task. For example A may offer to B that if you build this wall, I will pay you $\$ 100$. The contract of $J u$ allah could have a useful role in the area of issuing of letters of guarantee by Islamic banks. However, the classical fiqh literature is almost unanimous to the point that the guarantee is a charitable transaction and no fee can be charged on a guarantee. The most the guarantor can do is to claim his actual secretarial expenses incurred in offering the guarantee. Usmani (2004, pp.130-131) notes that some contemporary scholars are considering the problem from a different angle. They feel that guarantee has become a necessity, especially in international

\footnotetext{
9 See Usmani (2004), p.217.

10 See the International Islamic Fiqh Academy, Jeddah, Resolution No. 101 (4/11), 1998.
} 
trade where the sellers and the buyers do not know each other, and the paymem of the price by the purchaser cannot be simultaneous with the supply of the goods. There has to be an intermediary who can guarantee the payment. It utterly difficult to find the guarantors who can provide this service free of charge in required numbers. Keeping these realities in view, some Sharı̄' ah scholars of our time say that the prohibition of guarantee fee is not based on any specific injunction of the Holy Quran or the Sunnah of the Prophet. It has been deduced from the prohibition of rib $\bar{a}$ as one of its ancillary consequences. Moreover, guarantees in the past were of simple nature. In today's commercial activities, the guarantor has to bear some costs for giving the guarantee. Therefore, they opine, that the prohibition of guarantee fee should be reviewed in this perspective. In practice, Islamic banks are using this contract for providing letters of credit and letters of guarantee to their clients.

\subsection{Sukūk}

Sakk (singular of $S u k u \bar{k}$ ) literally means cheque or promissory note for receivable. Technically $S u k \bar{u} k$ refer to financial instruments meant to mobilize resources from the market based on the strength of one's balance sheet, credentials, track record, goodwill and prospects of the proposed project. They are meant to provide an Islamic alternative to conventional bonds. Sukūk can play a positive role in mobilization of savings on a vast scale. They benefit investors as well as those who have projects to finance that bear the promise of eventually generating sufficient revenue to meet the costs yet leave a surplus. Their proliferation increases the efficiency of the financial system. Also, they are capable of meeting credit needs of government and businesses in a manner that keeps credit supply linked with real assets.

Financial engineers have come up with fancy, names for various types ${ }^{11}$ where 'engineering' is more in names than in substance. The basic ideas are quite simple. Sukūk are basically, certificates based on ownership of certain assets. Generally, these certificates are negotiable in secondary markets. They represent 'ownership' in the assets underlying the issue. Those with variable returns are based on mudārabah or mushärakah. There are also Sukūk with predetermined, fixed income streams. The most popular of these is the one based on ijārah, (lease). There are Sukūk based on salam or istisnah contracts. Also there are hybrid issues whose underlying assets are mixtures of these. Murābahah receivables being debt obligations are not considered fit for $S u k \bar{u} k$ issue. But they have been accepted in such a mixture as long as they are in a minority. Due to this last point, while $S u k \bar{u} k$ offer a usefully potential mechanism for secondary market resource mobilization, they also open the way for sale of debt receivables (as minority share in a general $S u k \bar{u} k$ issue). Since, the sale of debt except at its face value is not generally acceptable by Islamic jurists, the use of $S u k \bar{u} k$ where debt receivable are a noticeable proportion, remain suspect from a Sharı̄' ah point of view.

\footnotetext{
${ }^{11}$ For various types of $S u k \bar{u} k$ in vogue, please see the paper of Meysam Safari in this issue.
} 
As Ariff (2012) points out, Sukūk have several advantages over conventional bonds, for which $s u k \bar{u} k$ provide an alternative. These include:

- $\quad$ First, large firms with a sure profit track are not afraid of sharing part of their profits with long term $S u k \bar{u} k$ investors. These investors will not sell off at the first signs of bad news because of the enshrined risk-sharing design of contracts. These fundamental differences in the contract structures lead to a new capital market product called the $S u k \bar{u} k$ certificate, which was first issued for public trading in 2000.

- $\quad$ Second, while there is transfer of assets to lenders, the assets are going to be returned to the borrower once debt is repaid, a strong incentive to limit debt.

- Third, because these investors want to avoid dealing in usury and interests (so it becomes an Islamic finance product), they are known to hold on to their security until maturity much more than would common bond investors.

Studies also show that, over its 12-year history, the yield is higher by a margin of about 10-40 basis points in low risk cases (government debt) and about 110 basis points in high risk cases (corporate debt). Profit sharing is only slightly more expensive than a one-sided contract that requires a no-default coupon payment with no regard to the outcome of investments!

\section{Combination of Products in One Contract}

Most modern contracts are hybrid contracts in which more than one product and/ or their basic terms and conditions, are incorporated. It is, therefore, important to explain the rules governing such combinations. As standalone contracts, each component may be permissible but the combination as a whole may have the end result similar to a prohibited contract. In Islamic law, it is not only the words of the contracts that are important. The spirit of the law must be reflected in the end result. Many Qurãnic verses and Ahādīth heap disdain on attempts to avoid the spirit of the law through subterfuges or going around the bush. In general the following principles should be observed in designing any contract structure to be Sharī’ah-compliant.

\subsection{The Combination Must Not Contradict an Explicit Text}

If there is an explicit text in the primary sources of Islamic law that certain types of contracts cannot be combined, for whatever reason, then any structure that involves such a combination becomes unacceptable. If analysed, the rationale of prohibition can also be found. Some examples are:

i) It is prohibited to combine a loan contract with a sales contract. Rationale: If allowed, a lender may advance the loan on an interest-free basis in the loan part of the deal but they can buy something at a cheaper price in the sale part of the deal which amounts to ribā. 
ii) The Prophet prohibited "two deals in one". Some scholars take this hädīth as a general prohibition of combining contracts. However, actually it implies that if more than one option is offered, one must be chosen before the deal is finalised. Rationale: Such combination amounts to gharar in the combined contract, which is prohibited in business contracts.

\subsection{Not Trying to Go Around the Bush}

A product structured on the basis of a combination of contracts should not be intended to circumvent impermissible transactions. Such attempts are called $h$ iyal (legal artifices) and are not generally allowed. For example, the Prophet (pbuh) prohibited bay 'al-inah, which is a sale and buy-back arrangement. For example, A sells his house to B for a cash price of US\$500,000 and simultaneously buys it back from B at a credit price of US\$600,000. It is easy to see that the end result is exchange of $\$ 500,000$ now for US\$600,000 later. This is nothing but riba $\bar{a}$. The "selling" and "buying back" of the house is inconsequential. The recent 'Sukūk debacle' was a result of similar commitment.

\subsection{The Combination Must Not Involve Contradictory Contracts/Conditions}

Each type of contract has unique legal implications and obligations. Contracts which are mutually contradictory cannot be combined. If the legal consequences do not conflict each other then there is no problem in combining them. For example, a collateral condition supports a loan contract and is hence acceptable. On the other hand, a condition in a marriage contract stipulating that the spouses will live apart, defeats the purpose of the contract and is hence not acceptable.

\subsection{The Combination Must Not Involve Contingent Contracts}

The Prophet (pbuh) has prohibited a sale that is circumscribed with a condition (bay wa shar). If the combination is such that the execution of one contract is contingent upon another contract, such combination is not permissible. For example, William saying to Peter that I sell my house to you provided Nancy rents her house to me.

\section{Summary and Conclusions}

Even though Islamic banks emerged in response to the market needs of Muslim clients, they are not religious institutions. Like other banks, they are profit seeking institutions. While it is the preferred way of banking for one fifth of humanity, it offers a wider choice of financial products to all. Several potential benefits can arise from the emergence of Islamic banking. These include:

i) The range of contracts available to savers and entrepreneurs is widened. The menu ranges from low risk trade-linked products to high risksharing contracts. 
ii) The financial system is enriched by the establishment of financial institutions with different modus operandi. This diversity enhances the stability of the financial system because the behavioral characteristics of different types of banks are likely to vary.

iii) Competition among alternative banking models is expected to increase the efficiency of the financial system.

iv) The financial needs of Muslims can be met in accordance with their faith. Since the public's acceptance of the services provided by the industry play a vital role in creating stable and efficient markets, plurality and inclusiveness are important for the development of financial markets.

v) The allocation of financial resources on the basis of profit-and-loss sharing (PLS) gives maximum weight to the profitability of investment as compared with credit worthiness in the conventional system. Such allocation of resources is expected to be more efficient than that on the basis of interest.

vi) As a result of PLS contracts, the liabilities side of the balance sheet tends to become symmetrical with the assets side. This helps making Islamic banks less vulnerable to external shocks and insolvency.

vii) The liability to share bank losses by investment depositors motivates them to be more vigilant about the operations of their banks and to demand greater transparency and more effective audit. Banks are also under pressure to evaluate their clients' projects more carefully and to monitor the risks more effectively.

viii) Since in the case of both profit-sharing and sale-based contracts, bank assets are created in response to investment opportunities in the real sector of the economy, and all financing is linked to commodities or assets, the real factors related to the production of goods and services (rather than speculative maneuvers) become the prime determinants of the rates of return.

ix) Debt creation in Islamic finance is generally not possible without the backing of goods and services. Monetary expansion would thus tend to take place in step with the growth of the real economy. This is expected to control inflationary pressures.

x) Destabilizing speculation would also be significantly curtailed as would the erratic and mass movement of short-term funds. That will provide a formidable protection against economic and financial instability.

xi) The Islamic alternative for interest-based bonds, $s u k \bar{u} k$, is a potent financial product that can meet the needs of the corporate and government sectors, but ensuring that their debts do not become unsustainable.

xii) Like 'Ethical Funds', Islamic banks do not provide finance to projects considered socially undesirable. That introduces greater social responsibility.

In brief, Islamic banking should contribute to greater allocative efficiency, market discipline, financial stability and social responsibility. In a world beset with financial crises, these strengths inherent in Islamic banking 
should offer a new ray of hope for achieving the cherished goal of systemic stability.

The experience of the last 50 years has shown that Islamic banking is a viable, dependable and well-supervised activity. It is just another way of performing the financial intermediation function. Islamic banks are subject to the same regulatory standards and fall under the purview of the same supervisory authorities as conventional banks. In addition they have to comply with the Islamic rules which mean that their overall legal and supervisory environment is more stringent. In brief, Islamic banking adds a healthy dimension to the international financial system.

Author information: Munawar Iqbal, $\mathrm{PhD}$, is a professor at the Institute of Islamic Economics, King Abdul Aziz University, Saudi Arabia. He is a founder of the International Association of Islamic Economics as well as first editor of two professional journals, The Review of Islamic Economics and the Islamic Economic Studies. He has taught and researched on this topic for several decades, having published more than forty books/articles. He lectures and conducts training in Islamic finance throughout the world. The author wishes to record his gratitude to the two anonymous referees and the editors of the Journal for providing review comments on an earlier version of this paper. Munawar may be contacted at: E-mail: munawariqbal@gmail.com.

\section{References}

Ariff, M. (2012). The search for a better debt instrument. October, 24. Retrieved from elgarblog.wordpress.com

Ariff, M., Iqbal, M. \& Mohamed, S. (Eds). (2012). The Islamic debt market for sukuk securities: The theory and practice of profit sharing investment. New York, US and Cheltenham, U.K: Edward Elgar.

Askari, H., Iqbal, Z., Krichene, N. \& Mirakhor, A. (2012). Risk sharing in finance: The Islamic finance alternative. Singapore: John Wiley and Sons.

Umer Chapra, M. (2000). International financial stability: The role of Islamic finance. Policy Perspectives, Vol. 4, No. 2.

Darir al- Siddiq. (2012). Gharar: Impact on Contracts in Islamic Fiqh, Jeddah: Dallah al-Barakah.

Iqbal, M. \& Llewellyn, D. T. (2002). Islamic banking and finance: New perspectives on profit sharing and risk. New York, US and Cheltenham, U.K: Edward Elgar.

Iqbal, M., \& Molyneux, P. (2005). Thirty years of Islamic banking: History, performance and prospects. Houndsmill, UK and New York, USA: Palgrave McMillan.

Iqbal, M. (2013). Determining the role of debt in the economy and a new approach for solving sovereign debt crises. International Journal of Banking and Finance, 10(1), 99-130. 
International Journal of Banking and Finance, Vol. 10, Iss. 2 [2013], Art. 4

Mills, P. S. \& Presley, J. R. (1999). Islamic finance: Theory and practice. London: Macmillan.

Allais, M. (1993). The monetary conditions of an economy of markets: From the teachings of the past to the reforms of tomorrow. Jeddah: Islamic Research and Training Institute.

Reinhart, C. M. \& Rogoff, K. S. (2009). This time is different: Eight centuries of financial folly. Princeton, NJ: Princeton University Press.

Usmani, M. T. (2004). An introduction to Islamic finance. Karachi: Maktaba Ma'ariful Quran. 